The Spectrum of

\title{
Interconnection Standards
}

\section{Guide Integration of Distributed Energy Resources}

Across the United States, energy circles are buzzing about the promise of the smart grid - the digital electric power system that holds the potential to reduce greenhouse gas emissions, cut electricity costs, and improve our nation's energy independence and security. At the National Renewable Energy Laboratory (NREL), the concept is exciting, but it isn't new. Researchers here have been laying the foundation for the smart grid for more than a decade.

\section{IEEE 1547: Consensus Standard Paves the Way}

NREL researchers have always believed in the power of renewable energy to improve our country's future. But they also realized that for renewables to reach their full potential, a modern paradigm would be necessary for the electric power system at large.

In 1999, NREL began work to accelerate this change via the Institute of Electrical and Electronics Engineers (IEEE). The goal: to create consensus standards with participation from industry, utilities, government, and others to guide the integration of renewable and other small electricity generation and storage sources (or "distributed resources," a key aspect of the smart grid) into the electric power system. Over four years, NREL led a group of more than 400 participants in the development of IEEE 1547 Standard for Interconnecting Distributed Resources With Electric Power Systems. IEEE 1547 was approved in June 2003 and became an American National Standard.

Since that time, IEEE 1547 has become the primary standard for distributed resource interconnection. Three-fourths of the states have adopted, referenced, or used IEEE 1547 in the development of their own interconnection standards, and the Energy Policy Act of 2005 designated it as the national standard for the interconnection of distributed resources. This national uniformity has made the interconnection process faster and easier and has encouraged the integration of many new distributed resource projects.

"The whole idea of IEEE 1547 was to provide a national standard for interconnection of distributed generators with the grid," says Richard DeBlasio, IEEE 1547 chair and NREL's principal laboratory program manager of electricity programs. "It was a major breakthrough because up until 2000 or 2001, it was extremely difficult to even negotiate an interconnection."

\section{NREL Leads Smart Grid Interconnection Efforts ...}

IEEE 1547 has had a significant effect on how the energy industry does business, and it will continue to influence the way our electric power systems operate far into the smart grid future. Following on this success, NREL has continued the development of standards in the 1547 family to further encourage distributed resource interconnection.

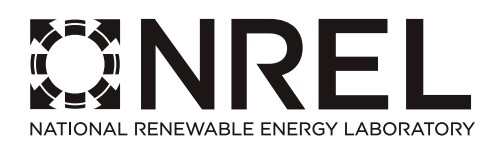

NREL is a national laboratory of the U.S. Department of Energy, Office of Energy Efficiency and Renewable Energy, operated by the Alliance for Sustainable Energy, LLC. 


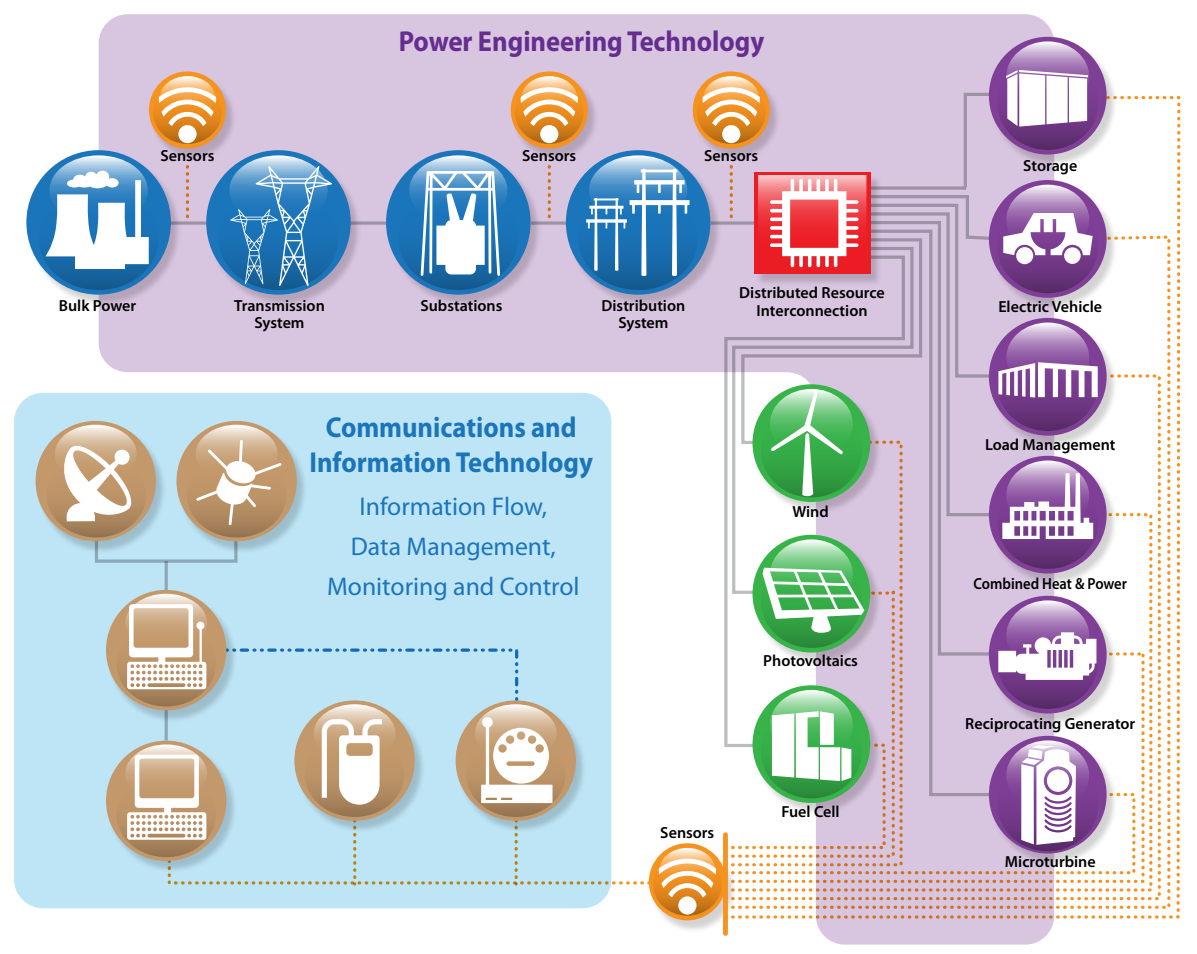

The smart grid is the integration of power engineering, communications, and information technologies.

To date, three additional smart grid interconnection standards have been passed:

- IEEE 1547.1 Standard for Conformance Test Procedures for Equipment Interconnecting Distributed Resources With Electric Power Systems (Approved 2005)

- IEEE 1547.2 Application Guide for IEEE 1547 Standard for Interconnecting Distributed Resources With Electric Power Systems (Approved 2008)

- IEEE 1547.3 Guide For Monitoring, Information Exchange, and Control of Distributed Resources Interconnected with Electric Power Systems (Approved 2007).

Four smart grid interconnection standards are still in development:

- IEEE P1547.4 Draft Guide for Design, Operation, and Integration of Distributed Resource Island Systems With Electric Power Systems

- IEEE P1547.5 Draft Technical Guidelines for Interconnection of Electric Power Sources Greater Than 20 MVA to the Power Transmission Grid

- IEEE P1547.6 Draft Recommended Practice for Interconnecting Distributed Resources With Electric Power Systems Distribution Secondary Networks

- IEEE P1547.7 Draft Guide to Conducting Distribution Impact Studies for Distributed Resource Interconnection.

\section{... And Mobilizes for Smart Grid Interoperability}

Based on the success of its IEEE 1547 initiatives, NREL expanded its standards leadership in the smart grid arena. IEEE P2030 Draft Guide for Smart Grid Interoperability of Energy Technology and Information Technology Operation With Electric Power System and End-Use Applications and Loads, which NREL initiated in November 2008, will establish a shared knowledge base to define smart grid interoperability and the integration of power engineering, information, and communications technologies.

Like IEEE 1547, IEEE P2030 is likely the first in a series of related standards projects. "I see this as a tree from which will spring a variety of standards," says DeBlasio, who is also the IEEE P2030 chair. "We want to look at everything from power generation to home appliances and the useful two-way communications between them."

\section{What Is the Smart Grid?}

You've probably heard about the "smart grid." It represents a transformation of the U.S. electric power system, and it's on everyone's minds. President Obama has made the creation of a new energy economy a priority for our nation's economic recovery —and the smart grid is the key to making it happen. But what is the smart grid?

The definition of a smart grid is broad and encompasses many aspects of electric grid operation and management. The smart grid uses digital technology to improve the reliability, security, and efficiency of the existing electric power system and enables greater use of electricity generated from renewable resources.

The smart grid will do these things:

- Boost the U.S. economy with an influx of new products, services, and markets

- Enable grid integration of large-scale renewable energy and distributed energy sources

- Self-heal in the event of power disturbances

- Reduce transmission and distribution inefficiencies

- Allow consumers to gain greater control over their energy costs

- Supply the high-quality power required by modern electronic equipment

- Provide grid operators with a quantum improvement in monitoring and control capabilities.

"We're on the cusp of this new energy future," said President Obama in a speech announcing a \$4.3-billion investment into smart grid technologies. "In fact, a lot of it is already taking place. ... At this moment, there is something big happening in America when it comes to creating a clean energy economy."

NREL is paving the way.

\section{National Renewable Energy Laboratory}

1617 Cole Boulevard

Golden, Colorado 80401-3305

303-275-3000 • www.nrel.gov

NREL is a national laboratory of the U.S. Department of Energy, Office of Energy Efficiency and Renewable Energy, operated by the Alliance for Sustainable Energy, LLC.

NREL/FS-6A4-47562 • June 2010

Printed with a renewable-source ink on paper containing at least $50 \%$ wastepaper, including $10 \%$ post consumer waste.

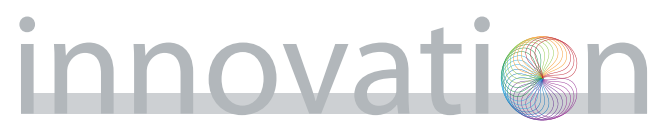

